\title{
ЛИТОЛОГО-ФИЗИЧЕСКИЕ КРИТЕРИИ ОПТИМИЗАЦИИ ТЕХНОЛОГИИ ГЛИНОКИСЛОТНОЙ ОБРАБОТКИ ТЕРРИГЕННЫХ КОЛЛЕКТОРОВ
}

\section{В.Ф.Калинин \\ Саратовский государственный университет, кафедра геологии и геохимии горючих ископаемых E-mail: decanat@geol.sgu.ru}

Представлены результаты лабораторных и промысловых исследований по оптимизации проведения глинокислотных обработок в скважинах, вскрывших терригенные коллекторы на месторождениях ОАО «Саратовнефтегаз». Показано, что эффективность глинокислотных обработок скважин определяется степенью соответствия режима обработки пласта его геолого-физической характеристики. Полученные результаты представляют практический интерес в вопросах обеспечения высокой эффективности работ по интенсификации притоков нефти и газа при освоении скважин.

\section{Lithological and Physical Yardsticks on Optimization Technology of Mud Acid Treatments Terrigenous Reservoirs}

\section{V.F. Kalinin}

Results of laboratory and field researches on optimization of realization of mud acid treatments in the wells, opened terrigenous reservoirs at Saratovneftegaz OAO deposits, are submitted. it is shown, that efficiency of mud acid treatments of wells is determined by a degree of conformity of a mode of treatment of a layer with its geologicalphisical characteristic.

Реализация потенциальной продуктивности скважин при их заканчивании достигается либо путем сохранения естественной гидропроводности пласта при его вскрытии и освоении скважины, либо за счет восстановления и увеличения гидропроводности призабойной зоны пласта (ПЗП) с помощью методов интенсификации притоков нефти и газа на этапе освоения скважины.

При оптимальном выборе технологии заканчивания скважин, соответствующей геологофизической характеристике пласта, возможно во многих случаях предотвратить или существенно ослабить развитие широкомасштабных негативных процессов, снижающих продуктивность скважины.

Однако в полной мере реализовать потенциальную продуктивность скважин при их заканчивании зачастую не представляется возможным, особенно при вскрытии продуктивных пластов с трудноизвлекаемыми запасами, характеризующихся высокой глинистостью, низкими фильтрационно-емкостными параметрами, порово-трещинным или трещинным типом коллектора.

При вскрытии продуктивных пластов со сложной геолого-физической характеристикой в

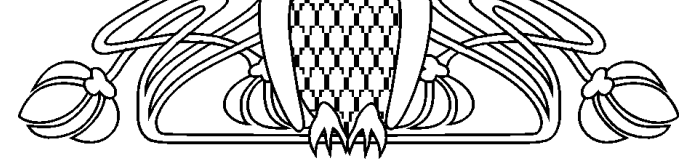

призабойной зоне пласта образуется труднопреодолимая блокада, обусловленная кольматацией породы-коллектора, набуханием его глинистой фазы и др., в совокупности приводящих к значительному снижению продуктивности скважины.

Нередко масштабы отрицательного влияния указанных видов осложнений на снижение продуктивности скважины настолько велики, что могут привести к полному нарушению ее гидродинамической связи с пластом, особенно в скважинах с закрытым забоем.

В этих условиях для восстановления гидродинамической связи пласта со скважиной и повышения продуктивности пласта используется целый ряд методов интенсификации притоков нефти и газа (химические, физические, механические, тепловые или их комбинации), отличающихся по своей эффективности, механизму их физикохимического воздействия на призабойную зону пласта, технико-технологическим возможностям самих методов и геолого-физическими условиями их применения.

Выбор оптимального метода интенсификации притоков нефти и газа при освоении скважин, законченных бурением, многофакторный процесс и эффективность его применения определяются, прежде всего, геолого-физической характеристикой пласта (типом коллектора, его литологией, пористостью, проницаемостью, глинистостью, карбонатностью, трещиноватостью, термобарическими условиями, глубиной залегания продуктивного пласта, его толщиной, удельной поверхностью фильтрации породы, ее смачиваемостью, видами и масштабами осложнений, возникающих в призабойной зоне пласта при заканчивании скважин).

Характерной особенностью терригенных коллекторов месторождений Саратовского Поволжья (Разумовское, Тепловское, Придорожное, Осиновское и др.), определяющей выбор метода интенсификации притоков нефти и газа, является поровый тип коллектора, низкие фильтрационно-емкостные параметры пласта, большая удельная поверхность фильтрации, довольно значительное содержание глинистого вещества в породе пласта, высокие пластовые давления и температуры $\left(P_{\text {пл }} \geq 25,0-40,0\right.$ МПа и более, $t_{\text {пл }}=70-100^{\circ} \mathrm{C}$ и более), способность коллекторов блокироваться фильтратом глинистого раствора или других технологических жидкостей на водной основе с 
резким снижением при этом их проницаемости вследствие гидрофилизации и гидратации коллектора.

Месторождения, приуроченные к терригенным коллекторам данного типа, относятся к категории месторождений с трудноизвлекаемыми запасами, характеризующихся низкой продуктивностью при их освоении.

Глубина залегания терригенных продуктивных пластов данного типа на месторождениях OAO «Саратовнефтегаз» достигает 3000-4000 м и более.

По результатам изучения керна, промысловогеофизических и гидродинамических исследований скважин пористость данного типа терригенных коллекторов изменяется в основном в пределах $m=7,0-14,0 \%$, относительная глинистость породы составляет $\eta=7,0 \div 15,0 \%$, проницаемость коллекторов изменяется в пределах $k=0,001-$ 0,1 мкм $^{2}$, и лишь по отдельным пропласткам с низкой глинистостью и повышенной пористостью проницаемость их достигает $k=0,085 \div 0,365$ мкм $^{2}$.

Пустотное пространство терригенных коллекторов сформировано из поровых каналов весьма малых размеров и изменяется в основном в пределах $2,0 \div 5,0$ мкм, и лишь в пропластках с низкой глинистостью и повышенной проницаемостью размеры поровых каналов достигают $7,0 \div 9,0$ мкм и более.

Отличительной особенностью коллекторов данного типа, определяющей выбор метода интенсификации притоков нефти и газа при освоении скважин, является высокая удельная поверхность фильтрации породы, достигающая для низкопроницаемых пропластков порядка $S_{\phi}=10000 \div 15000 \mathrm{~cm}^{2} / \mathrm{cm}^{3}$.

Карбонатность терригенных коллекторов незначительна и составляет $0,42 \div 0,68 \%$.

По минералогическому составу глинистая фаза коллектора представлена набухающими глинистыми минералами типа смектита и деградированной слюды, которые в присутствии пресной воды или фильтрата бурового раствора на водной основе могут довольно интенсивно набухать, увеличиваясь при этом в объеме в $1,5 \div 2,0$ раза и более, и диспергировать на мелкие частицы, уменьшая таким образом проводимость поровых каналов, и в целом снижая проницаемость породы-коллектора.

Основными терригенными объектами освоения на месторождениях Саратовского Поволжья являются ардатовские, тиманско-пашийские и воробьевские отложения, которые на Разумовской, Тепловской, Придорожной и Осиновской площадях залегают на глубинах до 3000-4000 м и более.

Исходя из литолого-физической характеристики данного типа терригенных коллекторов и прогноза видов осложнений, развивающихся в ПЗП при вскрытии пласта и освоении скважин, можно сделать вывод, что основными наиболее перспективными методами интенсификации притоков нефти и газа при освоении скважин на указанных площадях являются химические методы (глинокислотная обработка пласта).

Глинокислотная обработка (ГКО) терригенных коллекторов как один из методов интенсификации представляет по своим технологическим возможностям мощное средство повышения продуктивности добывающих скважин. Успешность операций определяется оптимальным выбором технологии ГКО, соответствующей литологофизической характеристике пласта.

Важное значение при этом придается рецептуре глинокислотного раствора. Обычно применяемый глинокислотный раствор, представляющий собой смесь соляной и плавиковой кислот в различных пропорциях, должен в оптимальной мере соответствовать литолого-физической характеристике породы-коллектора (пористости, проницаемости, глинистости и др.), обеспечивая максимальное увеличение проницаемости коллектора.

Исследования показали (табл.1), что растворимость песка и глины в смеси соляной и плавиковой кислоты возрастает по мере увеличения содержания плавиковой кислоты.

Таблица 1

Растворимость песка

и глины в глинокислотном растворе

\begin{tabular}{|c|c|c|c|}
\hline \multicolumn{2}{|c|}{$\begin{array}{c}\text { Содержание кислоты } \\
\text { в смеси, \% }\end{array}$} & \multicolumn{2}{c|}{ Растворимость, \% } \\
\hline Соляная & Плавиковая & Песок & Глина \\
\hline 15 & - & 18,28 & 11,2 \\
\hline 14,7 & 0,8 & 21,83 & 22,83 \\
\hline 13,2 & 4,8 & 23,56 & 52,07 \\
\hline 11,25 & 10,0 & 26,26 & 70,10 \\
\hline
\end{tabular}

При выборе рецептуры глинокислотного раствора необходимо учитывать определенные особенности реагирования глинокислотных растворов с терригенными заглинизированными коллекторами, обеспечивающие эффективность работ по интенсификации притоков нефти и газа.

При этом влияние термобарических условий пласта проявляется следующим образом.

Скорость реакции плавиковой кислоты с двуокисью кремния возрастает по мере увеличения температуры приблизительно в 2 раза - от 25 до $50^{\circ} \mathrm{C}$ и соответственно в 2 раза при дальнейшем росте температуры от 50 до $80^{\circ} \mathrm{C}$.

Пластовое давление также способствует росту скорости реакции плавиковой кислоты с двуокисью кремния приблизительно на 20\% за счет сохранения в растворе газообразного четырехфтористого кремния.

Характер взаимодействия плавиковой кислоты с силикатными материалами (кварцем, глиной (каолином)) протекает следующим образом: 


$$
\underset{\text { кварџ }}{\mathrm{SiO}_{2}}+4 \mathrm{HF}=2 \mathrm{H}_{2} \mathrm{O}+\mathrm{SiF}_{4} \uparrow,
$$

$$
\mathrm{H}_{4} \mathrm{Al}_{2} \mathrm{Si}_{2} \mathrm{O}_{9}+14 \mathrm{HF}=2 \mathrm{AlF}_{3}+2 \mathrm{SiF}_{4}+9 \mathrm{H}_{2} \mathrm{O} \text {. }
$$

Первая реакция идет медленно. Вторая реакция с алюмосиликатами (каолином) протекает достаточно быстро, хотя и значительно медленнее, чем реакция $\mathrm{HC} 1$ с карбонатами.

Образовавшийся в результате приведенных реакций $\mathrm{SiF}_{4}$ (фтористый кремний) реагирует с водой раствора по схеме

$$
2 \mathrm{SiF}_{4}+4 \mathrm{H}_{2} \mathrm{O}=\mathrm{Si}(\mathrm{OH})_{4}+2 \mathrm{H}_{2} \mathrm{SiF}_{6} .
$$

По мере снижения кислотности раствора $\mathrm{Si}(\mathrm{OH})_{4}$ может превратиться из золя в студнеобразный гель, прочно запечатывающий часть порового пространства пласта. Для предупреждения образования в поровом пространстве пласта геля кремневой кислоты, а также для обеспечения более полного завершения реакции разложения силикатов плавиковая кислота применяется только в смеси с соляной кислотой.

При обработке терригенных коллекторов с более или менее равномерно рассечёнными частицами карбонатов головная часть солянокислотного раствора полностью их растворяет и, продвигаясь вглубь пласта, полностью нейтрализуется. Хвостовая же часть кислоты поступает уже в зону, полностью освобожденную от карбонатов головной частью кислоты.

Соляная кислота реагирует не только с карбонатами, но и в определенной степени с цементом и глинистой фазой коллектора, поэтому при длительном контакте соляной кислоты с породой пласта возможна ее полная нейтрализация.

В таком случае, как ранее упоминалось, возможно образование в пласте гидроокиси кремния, которая может привести к резкому снижению проницаемости. Именно поэтому ограничивается продолжительность реагирования глинокислотного раствора с породой пласта до 8-12 ч, после чего необходимо интенсивное удаление с забоя и призабойной зоны пласта продуктов реакции. Без своевременного удаления продуктов реакции из пласта данный способ может даже ухудшить проницаемость нефтяных и газовых пластов.

При воздействии соляной кислоты на глинистые компоненты скелета пласта помимо растворения окислов щелочных и щелочноземельных металлов происходит нежелательный процесс гелеобразования, который усиливается с ростом содержания $\mathrm{HC} 1$ в рабочем растворе.

При выборе агента для восстановления или повышения фильтрационных свойств сильно заглинизированных коллекторов необходимо иметь ряд данных о состоянии глинистых пород, прежде всего об их влажности, минералогическом составе, составе ионно-обменного комплекса, соотношении объемов глин и других пород, пористости, проницаемости и т.д.
Если глинистые породы коллекторов находятся в обезвоженном состоянии, то, видимо, действие как соляной, так и плавиковой кислоты или глинокислоты наряду с растворением карбонатных и кремнеземистых включений вызывает в некоторой степени рост объема частиц глины за счет набухания.

Набухание глин различных типов в любых полярных средах возрастает в последовательности каолинит-гидрослюдистые-бентонит, а для каждого типа глин в зависимости от состава ионнообменного комплекса набухание глин возрастает в последовательности $\mathrm{Ca}<\mathrm{Fe}<\mathrm{Al}<\mathrm{H}<\mathrm{Na}<\mathrm{Li}$; т.е. в наименьшей степени набухают глины, имеющие в своем составе ионно-обменный комплекс типа $\mathrm{Ca}$ и в наибольшей степени типа $\mathrm{Na}$ и Li.

Так как натриевые глины более гидрофильны, чем кальциевые, то при натриевых глинах снижение проницаемости призабойной зоны пласта будет больше, чем при кальциевых.

Чем сильнее набухает глина в воде, тем больше будет прирост ее объема в любой полярной жидкости (кислотах, основаниях, солях). Следовательно, кислотная обработка может быть наиболее эффективной при наличии в коллекторе небольших количеств обезвоженных глин, т.е. в таких условиях, когда степень набухания глины будет превышать степень растворения карбонатных и кремнеземистых соединений.

Допустимое количество глин - относительно большое для кальциевых каолинитовых глин и наименьшее для натриевых бентонитовых глин. При наличии в коллекторе в больших количествах обезвоженных сильно набухающих глин действие полярных жидкостей (кислот) может оказаться даже отрицательным. Если глины, содержащиеся в коллекторах, находятся уже в набухшем состоянии, то применение полярных жидкостей для улучшения проницаемости этих коллекторов будет безрезультатным.

При определении концентрации кислоты необходимо учитывать также и влияние ее на набухание глин.

$5 \% \mathrm{HC} 1$ снижает набухание гидратированных глин до $K_{1}=2,1$, процесс идет 24 часа. В глинокислоте набухание глины значительно меньше, чем в HF различной концентрации, а процесс набухания заканчивается через 3-4 часа.

Соляная кислота растворяет продукты реакции между HF и глинами. В процессе реакции элементы кристаллической решетки минералов, составляющих глины, разрушаются и вместе с кремнекислотой переходят в раствор $\mathrm{Al}_{2} \mathrm{O}_{3}$, окислы железа с образованием комплексного иона $\left(\mathrm{FeF}_{6}\right)$.

С целью оптимизации технологии проведения глинокислотных обработок терригенных коллекторов на месторождениях Саратовского Поволжья нами были выполнены лабораторные исследования на керновом материале с помощью установки УИПК-1М по разработке наиболее эф- 
фективных рецептур глинокислотных растворов, выбору удельных объемов кислотного раствора, закачиваемого в пласт, изучению кинетики растворения породы в кислотных растворах, степени увеличения ее проницаемости при воздействии кислотного раствора и определения оптимального времени реагирования кислоты с породой.

Исследование кинетики процесса растворения терригенной породы (песчаника) в гли- нокислотных растворах показало, что процесс растворения терригенных пород коллекторов даже при высокой температуре до $100^{\circ} \mathrm{C}$ происходит значительно медленнее, чем карбонатных пород в солянокислотных растворах в тех же условиях. При этом наибольшая скорость растворения песчаника отмечается в глинокислотном растворе, включающем $4 \% \mathrm{HF}+14 \% \mathrm{HC} 1+4 \% \mathrm{CH}_{3} \mathrm{COOH}+1 \%$ сульфонола (рис. 1).

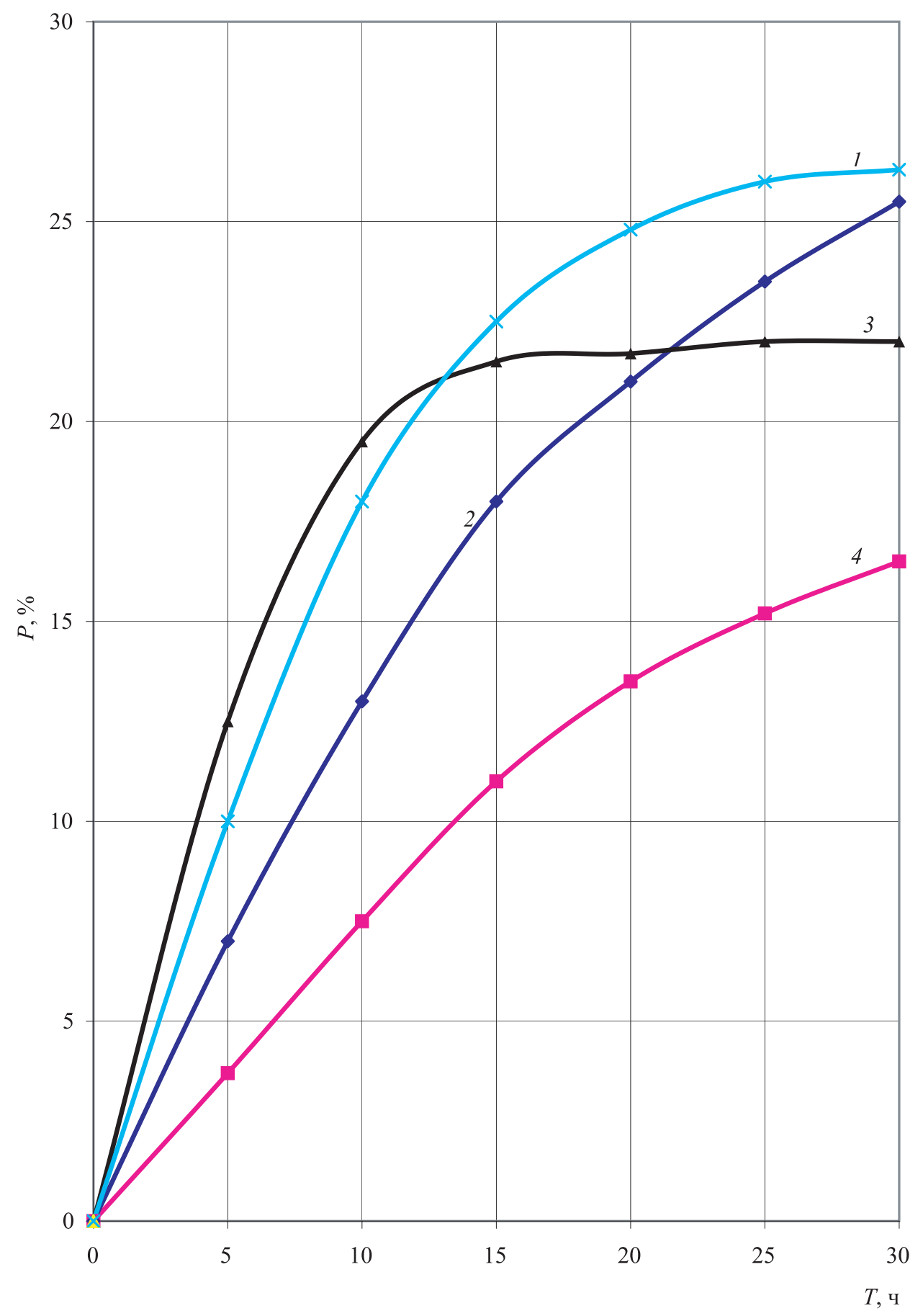

Рис.1. Зависимость растворимости песчаника от состава глинокислотного раствора и продолжительности его реагирования с породой: $1-4 \% \mathrm{HF}+14 \% \mathrm{HCL}+4 \% \mathrm{CH} 3 \mathrm{COOH}+1 \%$ сульфанола; $2-4 \% \mathrm{HF}+14 \% \mathrm{HCL}+4 \% \mathrm{CH} 3 \mathrm{COOH} ; 3-4 \% \mathrm{HF}+14 \% \mathrm{HCL}+0,5 \% \mathrm{O}-4 ; 4-4 \% \mathrm{HF}+14 \% \mathrm{HCL}+1 \%$ сульфанола 
Уже через 12-14 ч реагирования указанного глинокислотного раствора с песчаником практически завершается процесс химического взаимодействия породы с глинокислотным раствором. К этому времени растворимость породы достигает $19 \%$.

Растворимость песчаника в глинокислотном растворе, состоящем из $4 \% \mathrm{HF}+14 \% \mathrm{HC} 1+$ $+4 \% \mathrm{CH}_{3} \mathrm{COOH}+1 \%$ сульфонола, протекает в 4 раза интенсивнее, чем в глинокислотном растворе типа 4\% $\mathrm{HF}+14 \% \mathrm{HC} 1$ (см. рис. 1 ).

Результаты выполненных нами лабораторных исследований на керновом материале с помощью установки УИПК-1М показали, что при закачке глинокислотного раствора в низкопроницаемые чистые незакольматированные буровым раствором образцы песчаника проницаемостью $k=(4,6 \div 8,59) 10^{-3}$ мкм $^{2}$ происходит закономерное увеличение проницаемости породы в 3-40 раз и более уже через 12-14 ч реагирования ее с кислотным раствором при температуре проведения опыта 90-100 ${ }^{\circ} \mathrm{C}$ (рис. 2).

Дальнейшее увеличение продолжительности реагирования глинокислотного раствора с породой-коллектором до 22-25 ч лишь в отдельных случаях приводит к значительному, почти в 56,0 раз, росту проницаемости породы (см. рис.2).

Исследование влияния объема закачиваемого кислотного раствора в модель пласта на изменение его проницаемости, выполненное нами в лабораторных условиях с помощью установки УИПК-1М, показало, что оптимальные количества кислотного раствора, закачиваемого в пласт, определяются глубиной ухудшенной призабойной зоны пласта и его естественной фильтрационно-емкостной и литолого-физической характеристикой (пористостью, проницаемостью, глинистостью, минералогическим составом глинистого цемента, гранулометрическим составом породы и др.).

При этом чем меньше проницаемость пласта и выше глинистость, тем опаснее закачивать в пласт большое количество глинокислотного раствора, так как на периферии обработанной зоны выпадают гелеобразные продукты реакции, которые закупоривают поровое пространство пласта и трудно удаляются из призабойной зоны при освоении скважин.

Данные явления обусловлены следующими обстоятельствами.

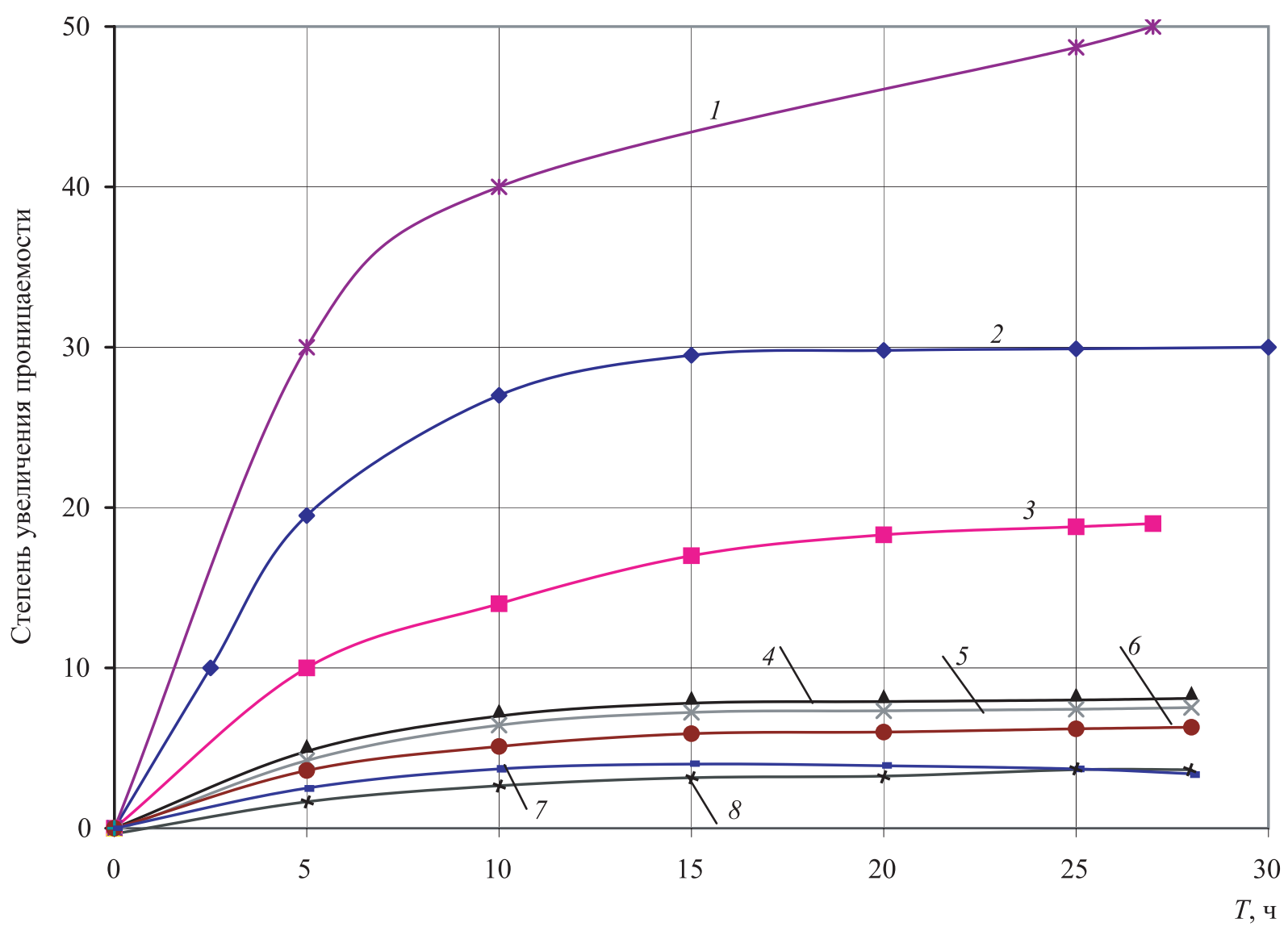

Рис. 2. Зависимость степени увеличения проницаемости песчаника от состава глинокислотного раствора и продолжительности его реагирования с породой: 1,6 - раствор, содержащий $4 \% \mathrm{HF}+4 \% \mathrm{CH} 3 \mathrm{COOH}+14 \% \mathrm{HCl}+1 \%$ сульфанола, взаимодействующий с породой проницаемостью $k$, равной соответственно $0,46 \times 10^{-3}$ и $3,46 \times 10^{-3}$ мкм $^{2}$;

$2,3,4,5$ - раствор, содержащий $4 \% \mathrm{HF}+14 \% \mathrm{HCl}, k$ составляет соответственно $4,5 \times 10^{-3} ; 4,15 \times 10^{-3} ; 9,78 \times 10^{-3}$ и $4,79 \times 10^{-3}$ мкм $^{2} ; 7$ - раствор, содержащий $4 \% \mathrm{HF}+14 \% \mathrm{HCl}+0,5 \%$ OП-4, $k=6,49 \times 10^{-3}$ мкм $^{2} ; 8$ - раствор, содержащий $4 \% \mathrm{HF}+4 \% \mathrm{CH} 3 \mathrm{COOH}+14 \% \mathrm{HCl}, k=8,59 \times 10^{-3}$ мкм $^{2}$ 
Скорость реагирования глинокислоты со слоистыми (глинистыми) силикатами (каолинитом, хлоритом), и в особенности с гидрослюдами, выше, чем с каркасными силикатами, вследствие своих кристаллохимических особенностей.

Следовательно, при реагировании глинокислоты с породой пласта степень разложения указанных минералов и количество образующихся продуктов реакции будут возрастать по мере увеличения глинистости коллектора свыше 6,0-10,0\%, количества гидрослюдистых минералов в породе пласта соответственно свыше $5,0-8,0 \%$, продолжительности реагирования кислоты с породой свыше 20 ч и увеличения соотношения объемов глинокислоты, закачиваемой в пласт, к объему порового пространства породы.

Учитывая довольно медленное реагирование глинокислотного раствора с терригенными породами, принимая во внимание нередко значительное снижение проницаемости коллекторов в ПЗП при их вскрытии в процессе бурения скважин и основываясь на результатах выполненных нами лабораторных исследований на керновом материале по оптимизации технологии глинокислотной обработки призабойной зоны пласта при освоении скважин, можно сделать следующие выводы:

1) в качестве глинокислотного раствора для восстановления фильтрационной характеристики призабойной зоны пласта при освоении скважин целесообразно применять кислотный раствор следующего состава: $4 \% \mathrm{HF}+14 \% \mathrm{HC} 1+4 \% \mathrm{CH}_{3} \mathrm{COOH}+1 \%$ сульфонола, обеспечивающий:

- довольно высокую степень восстановления естественной проницаемости коллекторов;

- достаточно высокую скорость реагирования его с породой пласта;

- предотвращение выпадения нерастворимых соединений в ПЗП за счет наличия в составе кислотного раствора уксусной кислоты;

- снижение гидрофилизации и гидратации коллекторов и более легкое извлечение продуктов реакции из пласта за счет наличия ПАВ в кислотном растворе;

2) удельные объемы глинокислотного раствора, закачиваемого в пласт при освоении скважин, изменяются в пределах $V_{\text {уд }}=0,5-0,6 \mathrm{~m}^{3} / \mathrm{M}$ для терригенных коллекторов с пониженной фильтрационно-емкостной характеристикой $\left(k=0,01-0,05\right.$ мкм $^{2}$ и $\left.\mathrm{m}=9,0-13,0 \%\right)$ и увеличиваются до $V_{\text {уд }}=0,715-0,75 \mathrm{~m}^{3} /$ м для терригенных коллекторов с улучшенной фильтрационно-емкостной характеристикой $\left(k=0,05-0,1\right.$ мкм $^{2}$ и более и $\mathrm{m}>13,0 \%$ );

3) продолжительность реагирования глинокислотного раствора в пласте возрастает по мере снижения давления закачки глинокислотного раствора в пласт и изменяется в пределах от 7,0-8,0 ч для низкопроницаемых коллекторов до 12-14 ч для более проницаемых малоглинистых коллекторов, обеспечивая таким образом оптимальную степень разложения глинистой фазы коллектора и предотвращая вторичную кольматацию пласта продуктами реакции;

4) закачку глинокислотного раствора в пласт необходимо осуществлять на медленных режимах при удельной объемной скорости закачки кислотного раствора в пласт в пределах $Q=0,7-1,0$ л/с $\cdot$ м.

Промысловые работы по восстановлению фильтрационной характеристики призабойной зоны пласта с помощью глинокислотной обработки в скважинах, законченных бурением, на Тепловском, Разумовском, Западно-Степном и Осиновском месторождениях подтвердили результаты лабораторных и экспериментальных исследований на модели пласта по выбору оптимальной технологии глинокислотных обработок при освоении скважин (табл. 2).

Практически во всех скважинах после проведения ГКО наблюдалось либо значительное, в 1,25 раза, увеличение продуктивности скважин (скв. 1 Разумовская площадь), либо были получены притоки нефти и газа дебитом $Q_{\mathrm{H}}=3,5-72,0 \mathrm{M}^{3} /$ сут в тех скважинах, в которых до проведения ГКО они отсутствовали или были крайне слабыми вследствие интенсивного развития кольматационных процессов при вскрытии пласта.

Так, в скв. 13 Тепловской площади при испытании пласта в процессе бурения с помощью испытателя пластов был получен интенсивный приток нефти со среднесуточным расчетным дебитом $Q_{\mathrm{H}}=70 \mathrm{~m}^{3} /$ сут. Однако после спуска эксплуатационной колонны, ее цементирования и перфорации пласта с помощью перфораторов ПКО-73 с плотностью перфорации $n=20$ отв/м приток из пласта при освоении скважины не был получен. После проведения глино-кислотной обработки пласта с закачкой в пласт $V_{\mathrm{k}}=5,0 \mathrm{M}^{3}$ кислотного раствора состава $4 \% \mathrm{HF}+14 \% \mathrm{HC} 1+4 \% \mathrm{CH}_{3} \mathrm{COOH}+1 \%$ сульфонола и выдерживания его на реагирование в пласте в течение 12-14 ч был получен фонтанный приток нефти дебитом $Q=72 \mathrm{~m}^{3} /$ сут.

Судя по начальному устьевому давлению закачки глинокислотного раствора в пласт, составлявшему $P_{\text {у.н }}=22,0 \mathrm{MПа,} \mathrm{и} \mathrm{конечному} \mathrm{давлению}$ закачки глинокислотного раствора в пласт $P_{\text {у.н }}=$ $=14,5 \mathrm{MПа,} \mathrm{в} \mathrm{призабойной} \mathrm{зоне} \mathrm{пласта} \mathrm{в} \mathrm{процессе}$ его вскрытия сформировалась довольно мощная зона кольматации, преодолеть которую не удалось при перфорации.

Последующие работы по освоению скважин с созданием достаточно высоких депрессий на пласт в пределах 15-16,0 МПа также оказались безуспешными.

Аналогичные явления наблюдались и при освоении скв. 7 и 9 Осиновской площади, где после перфорации ардатовских отложений с помощью сверлящих перфораторов типа ПС-112 с плотностью перфорации $n=10$ отв/м приток из пласта также не был получен, несмотря на создание достаточно высоких депрессий на пласт в пределах $\Delta P_{\text {д }}=15,0-16,0$ МПа. 
Таблича 2

Результаты работ по глинокислотной обработке терригенных коллекторов в скважинах, законченных бурением на месторождениях ОАО «Саратовнефтегаз»

\begin{tabular}{|c|c|c|c|c|c|c|c|c|c|c|c|c|c|}
\hline \multirow[b]{2}{*}{ 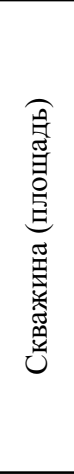 } & \multirow[b]{2}{*}{ 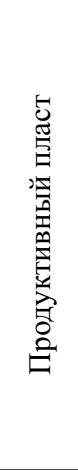 } & \multirow[b]{2}{*}{ 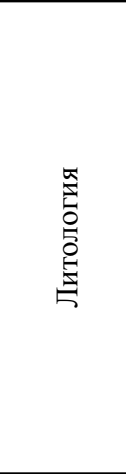 } & \multirow{2}{*}{ 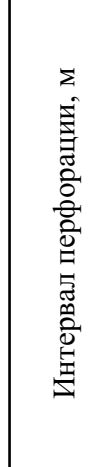 } & \multirow{2}{*}{ 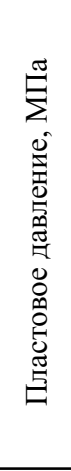 } & \multirow{2}{*}{ 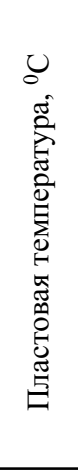 } & \multirow[b]{2}{*}{$\begin{array}{c}\text { Рецептура кислотного } \\
\text { раствора }\end{array}$} & \multicolumn{5}{|c|}{$\begin{array}{c}\text { Параметры процесса глинокислотной } \\
\text { обработки }\end{array}$} & \multicolumn{2}{|c|}{$\begin{array}{l}\text { Произв. } \\
\text { скважи- } \\
\text { ны, } \\
\mathrm{m}^{3} / \mathrm{cyт}\end{array}$} \\
\hline & & & & & & & 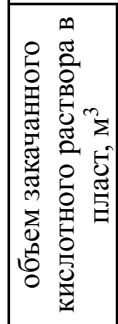 & 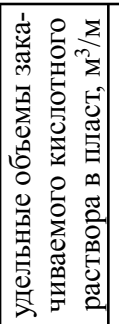 & 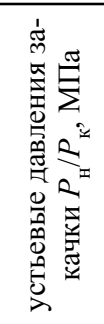 & 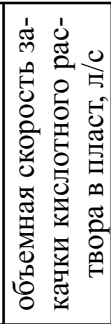 & 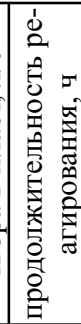 & 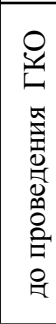 & 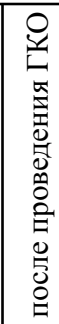 \\
\hline 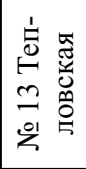 & 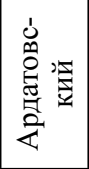 & 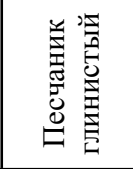 & 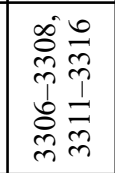 & 37 & 84 & $\begin{array}{l}4 \% \mathrm{HF}+14 \% \mathrm{HC} 1+ \\
+4 \% \mathrm{CH}_{3} \mathrm{COOH}+ \\
+1 \% \text { сульфонола }\end{array}$ & 5,0 & 0,715 & $22 / 14,5$ & 3,5 & $12-14$ & 0 & 72 \\
\hline 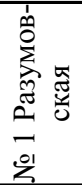 & 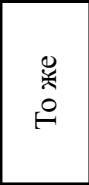 & 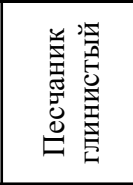 & 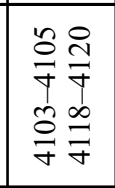 & 33,6 & 91,4 & $\begin{array}{l}4 \% \mathrm{HF}+14 \% \mathrm{HC} 1+ \\
+4 \% \mathrm{CH}_{3} \mathrm{COOH}+ \\
+1 \% \text { сульфонола }\end{array}$ & 3,0 & 0,75 & $23 / 15,5$ & 3,5 & 12-14 & 12 & 15 \\
\hline 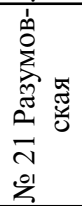 & $\hat{\imath}$ & 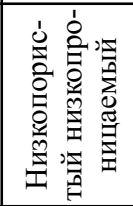 & 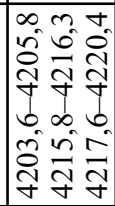 & 42 & 94 & То же & 3,0 & 0,55 & $32 / 21$ & 3,5 & $12-14$ & 0 & 10,7 \\
\hline 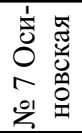 & $\hat{\wedge}$ & $\hat{\wedge}$ & $\begin{array}{l}b \\
\text { ते त̂ } \\
\text { ते }\end{array}$ & 24,5 & 60 & " & 2,5 & 0,735 & $22 / 19$ & 3,5 & $12-14$ & 0 & 9,5 \\
\hline 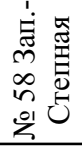 & 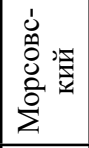 & $\hat{\imath}$ & $\begin{array}{l}1 \\
n \\
n \\
0 \\
0 \\
0 \\
0\end{array}$ & 40,0 & 90 & " & 1,5 & 0,6 & $27,5 / 16$ & 3,5 & $12-14$ & 0 & 5,0 \\
\hline 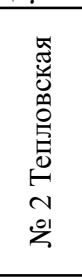 & 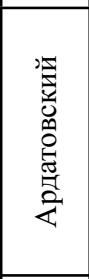 & 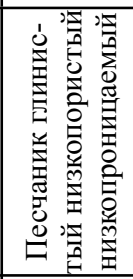 & $\begin{array}{l}0 \\
\vec{j} \\
\hat{m} \\
b \\
\vec{m} \\
m\end{array}$ & 37,0 & 85 & $\begin{array}{l}4 \% \mathrm{HF}+14 \% \mathrm{HC} 1+ \\
+4 \% \mathrm{CH}_{3} \mathrm{COOH}+ \\
+1 \% \text { сульфонола }\end{array}$ & 1,0 & 0,5 & $30 / 23$ & 3,5 & $12-14$ & 0 & 3,5 \\
\hline 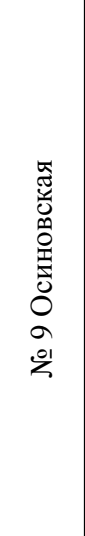 & $\hat{\wedge}$ & 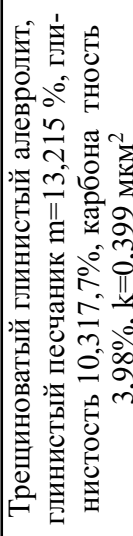 & 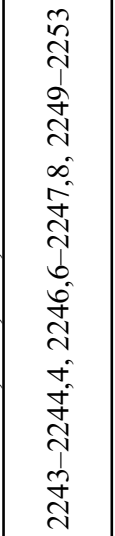 & 24,5 & 60 & То же & 2,5 & 0,38 & $18 / 14$ & 3,8 & $\mid 10-12$ & 0 & 40,5 \\
\hline
\end{tabular}


После проведения глинокислотной обработки пласта с закачкой в пласт $V=5,0 \mathrm{~m}^{3}, V=2,5 \mathrm{м}^{3}$ кислотного раствора соответственно в скв. 7 и 9 Осиновского месторождения была восстановлена гидродинамическая связь пласта со скважинами и получены притоки нефти соответственно $Q_{\mathrm{H}}=3,5 \mathrm{~m}^{3} /$ сут в скв. 7 Осиновского месторождения и $Q_{\mathrm{H}}=40,5 \mathrm{~m}^{3} /$ сут в скв. 9 Осиновского месторождения (см. табл. 2).

Образование довольно мощной блокады в ПЗП при вскрытии пласта и разрушение ее с помощью глинокислотной обработки отмечались также при освоении скв. 21 Разумовского месторождения, скв. 58 Западно-Степного месторождения и скв. 2 Тепловского месторождения.

При этом наблюдались высокие устьевые давления начала закачки глинокислотного раствора в пласт, достигающие $P_{\mathrm{y}}=32,0$ МПа в скв. 21 Разумовского месторождения, $P_{\mathrm{y}}=30,0$ МПа в скв. 2 Тепловского месторождения и $P_{\mathrm{y}}=27,5 \mathrm{MПа}$ в скв. 58 Западно-Степного месторождения, что свидетельствует об интенсивном блокировании ПЗП буровым раствором в процессе бурения скважины.

Полученные результаты свидетельствуют о достаточно высокой эффективности применения разработанной нами оптимальной технологии восстановления потенциальной продуктивности скважин, законченных бурением с помощью химических методов интенсификации притоков нефти и газа.

\section{Выводы}

1. Эффективность глинокислотной обработки терригенных коллекторов определяется геологотехнологическими факторами: литотипом коллектора, его фильтрационно-емкостными свойствами, глинистостью, минералогическим составом глинистой фазы коллектора, карбонатностью, термобарическими условиями и др., давлениями закачки глинокислотного раствора в пласт, рецептурой кислотного раствора, продолжительностью его реагирования в пласте, удельными объемами

УДК 553.98.2.078

\section{ПРОГНОЗ НЕФТЕГАЗОНОСНОСТИ НЕДР МЕТОДАМИ ГЛУБИННОЙ ГЕОХИМИИ}

\section{В.М. Мухин}

Саратовский государственный университет, кафедра геологии и геохимии горючих ископаемых E-mail: muchin@info.sgu.ru

В статье даётся краткий обзор существующих взглядов на возможность прогноза нефтегазоносности на основе изучения рассеянного органического вещества (РОВ) пород и его катагенетической изменённости. На примере южной части Бузулукской впадины прослежена связь катагенеза палеозойских пород с фазовым кислотного раствора, закачиваемого в пласт, и объемной скоростью его закачки в пласт.

2. В качестве оптимальной рецептуры глинокислотного раствора для восстановления проницаемости призабойной зоны пласта при освоении скважин целесообразно применять кислотный раствор следующего состава: $4 \% \mathrm{HF}+14 \% \mathrm{HC} 1+4 \% \mathrm{CH}_{3} \mathrm{COOH}+1 \%$ сульфонола, обеспечивающий наибольшую степень растворимости песчаников и увеличения их проницаемости.

3. Удельные объемы глинокислотного раствора, закачиваемого в пласт при освоении скважин, изменяются в пределах $V_{\text {уд }}=0,5-0,6 \mathrm{~m}^{3} /$ м для терригенных коллекторов с низкой фильтрационно-емкостной характеристикой $k=0,01-0,05$ мкм $^{2}$ и $m=9,0-13,0 \%$ и $V_{\text {уд }}=0,71-0,75 \mathrm{~m}^{3} / \mathrm{м}$ для терригенных коллекторов с проницаемостью $k=$ $=0,05-0,1$ мкм $^{2}$ и $m>13 \%$.

4. Оптимальная продолжительность реагирования глинокислотного раствора в пласте возрастает по мере снижения давления закачки глинокислотного раствора в пласт и изменяется в пределах от 7,0-8,0 ч для низкопроницаемых коллекторов и до 12-14 ч для более проницаемых низкоглинистых коллекторов в соответствии с условием обеспечения оптимальной степени разложения глинистого вещества в породе и предотвращения при этом вторичной кольматации пласта продуктами реакции.

5. Закачку глинокислотного раствора в пласт необходимо осуществлять на медленных режимах при удельной объемной скорости закачки кислотного раствора в пласт в пределах $Q=0,7-1,0$ л/с $\cdot$ м.

6. Промысловые работы по применению оптимальной технологии глинокислотных обработок при освоении 7 скважин на месторождениях ОАО «Саратовнефтегаз» показали весьма высокую ее эффективность.

Практически во всех скважинах после проведения ГКО отмечено значительное увеличение продуктивности скважин, составившее по отдельным скважинам до $70 \mathrm{~m}^{3} /$ сут.

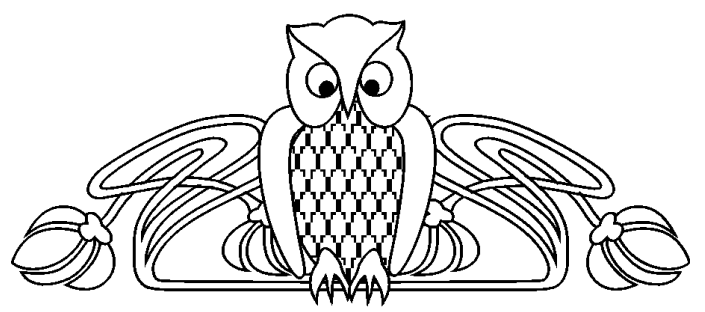

составом залежей углеводородов. Составлена оригинальная схема катагенетической зональности недр для этой территории на основании использования метода расчётов суммарных импульсов тепла. Предложено использовать данные определений катагенеза на нескольких стратиграфических уровнях в группе скважин для выявления математической связи степени его развития с современной глубиной залегания пород. 